\title{
PGRMC1 Gene
}

National Cancer Institute

\section{Source}

National Cancer Institute. PGRMC1 Gene. NCI Thesaurus. Code C128473.

This gene plays a role in progesterone binding. 